\title{
FAKTOR-FAKTOR YANG MEMPENGARUHI MASYARAKAT DESA CANDIKUNING MENJADI NASABAH PT. SUN LIFE FINANCIAL INDONESIA
}

\author{
Ni Ketut Oni Widarianti \\ Program Studi Pendidikan Ekonomi, Fakultas Ekonomi \\ Universitas Pendidikan Ganesha \\ Singaraja, Indonesia \\ e-mail: onniweda@gmail.com
}

\begin{abstract}
ABSTRAK
Penelitian ini bertujuan untuk (1) mengetahui faktor - faktor yang mempengaruhi Masyarakat Desa Candikuning menjadi Nasabah PT. Sun Life Financial Indonesia dan (2) faktor yang paling dominan mempengaruhi masyarakat Desa Candikuning menjadi Nasabah PT. Sun Life Financial Indonesia.

Jenis penelitian ini merupakan penelitian faktorial. Responden dalam penelitian ini berjumlah 100 orang masyarakat Desa Candikuning yang menjadi Nasabah PT Sun Life Financial Indonesia. Data dikumpulkan dengan menggunakan kuesioner dan dianalisis dengan analisis faktor melalui Statistical Program Social Scence (SPSS) 16.0 for windows.

Hasil penelitian menunjukkan bahwa (1) terdapat 4 faktor yang mempengaruhi masyarakat Desa menjadi nasabah PT Sun Life Financial Indonesia yaitu budaya, sosial, pribadi, psikologi. Besarnya variance explained masing-masing faktor tersebut secara berturut-turut, yaitu budaya sebesar $63,915 \%$, sosial sebesar $14,756 \%$, pribadi sebesar $13,588 \%$, dan psikologi sebesar $4,626 \%$. (2) faktor budaya menjadi faktor yang paling dominan yang memiliki variance explained tertinggi, yaitu sebesar $63,915 \%$, artinya total nilai variance explained dari faktor budaya mampu menjelaskan masyarakat Desa Candikuning yang menjadi Nasabah PT Sun Life Financial Indonesia.
\end{abstract}

Kata kunci: keputusan, masyarakat desa candikuning, PT. sun life financial indonesia.

\begin{abstract}
This study aims to (1) identify factors - factors and (2) the most dominant factor Candikuning Village Community Become a Customer PT. Sun Life Financial Indonesia.

This research was factorial study. Respondents in this study of 100 people who became village community Candikuning Customer PT Sun Life Financial Indonesia. Data were collected using a questionnaire and analyzed by factor analysis through Social Scence Statistical Program (SPSS) 16.0 for Windows.

The results showed that (1) there are four factors that affect people's participation in a customer Candikuning Village PT Sun Life Financial Indonesia, cultural, social, personal, psychological. The amount of variance explained each of these factors in a row, the culture of $63.915 \%, 14.756 \%$ of the social, personal amounted to $13.588 \%$, and the psychology of $4.626 \%$. (2) cultural factors into the most dominant factor that has the highest explained variance, that is equal to $63.915 \%$, meaning that the total variance explained from cultural factors are able to explain the villagers Candikuning that a customer of PT Sun Life Financial Indonesia. decision, villagers Candikuning, PT. Sun Life Financial Indonesia.
\end{abstract}

Keywords: decision, villagers Candikuning, PT. Sun Life Financial Indonesia. 


\section{PENDAHULUAN}

Asuransi dapat memberikan proteksi terhadap kesehatan, pendidikan, hari tua, harta benda maupun kematian. Salah satunya pada saat sekarang ini yaitu Sunlife Financial. Seorang manusia di dalam suatu masyarakat sering menderita suatu kerugian karena akibat dari suatu peristiwa yang tidak terduga semula, misalnya mendapat kecelakaan dalam perjalanan di darat, di laut atau di udara. Kalau kerugian ini hanya kecil sehingga dapat ditutup dengan uang simpanan, maka kerugian itu tidak begitu terasa. Lain halnya apabila uang simpanan tidak mencukupi untuk kerugian itu, maka orang akan betul-betul menderita. Untuk itulah, jaminan-jaminan perlindungan terhadap keadaan-keadaan tersebut di atas sangat diperlukan oleh setiap masyarakat yang ingin mengantisipasi apabila keadaan di luar dugaan yaitu risiko yang terjadi. Risiko tidak lain adalah beban kerugian yang diakibatkan karena suatu peristiwa di luar kesalahannya, misalkan rumah seseorang terbakar sehingga pemiliknya mengalami kerugian. Inilah resiko yang harus ditanggung pemiliknya. Risiko diartikan pula sebagai kerugian yang tidak pasti (uncertainty of financial loss) di dalamnya terdapat dua unsur, yaitu ketidakpastian dan kerugian. Karena besarnya resiko ini dapat diukur dengan nilai barang yang mengalami peristiwa di luar kesalahan pemiliknya, resiko ini dapat dialihkan pada perusahaan asuransi kerugian dalam bentuk pembayaran klaim asuransi. Pengalihan resiko ini diimbangi dalam bentuk pembayaran premi pada perusahaan asuransi kerugian (penanggung) setiap bulan atau tahun., bergantung pada perjanjian yang tertuang dalam polis. Manfaat peralihan resiko inilah yang diperoleh konsumen (tertanggung).

Perkembangan dunia dewasa ini ditandai dengan arus globalisasi di segala bidang yang membawa dampak cukup besar bagi perkembangan perekonomian Indonesia. Tingkat perkembangan ekonomi dunia dewasa ini ditandai dengan globalisasi di segala bidang yang diiringi pula oleh tingginya tingkat mobilitas penduduk, lalu lintas uang dan barang dalam arus perdagangan serta semakin pesatnya pertarungan bisnis. Di sisi lain beban tugas pemerintah semakin berat karena semakin tingginya tuntutan peningkatan kesejahteraan rakyat. Asuransi dalam Undang-Undang No. 2 Tahun 1992 tentang Usaha Perasuransian adalah perjanjian antara dua pihak atau lebih, dengan mana pihak penanggung mengikatkan diri kepada tertanggung, dengan menerima premi asuransi, untuk memberikan penggantian kepada tertanggung karena kerugian, kerusakan atau kehilangan keuntungan yang diharapkan atau tanggung jawab hukum pihak ke tiga yang mungkin akan diderita tertanggung, yang timbul dari suatu peristiwa yang tidak pasti, atau memberikan suatu pembayaran yang didasarkan atas meninggal atau hidupnya seseorang yang dipertanggungkan.

Dalam industri jasa yang paling banyak diatur lewat regulasi pemerintah adalah yang bergerak di bidang sektor jasa keuangan yang menghimpun dana dari masyarakat, seperti pada perbankan dan asuransi. Salah satu yang semakin berkembang seiring dengan meningkatnya kemakmuran rakyat adalah perkembangan industri asuransi . Dewasa ini industri asuransi telah menjadi suatu bidang usaha atau bisnis yang menarik dan mempunyai peranan yang tidak kecil dalam kehidupan ekonomi maupun dalam pembangunan ekonomi terutama dalam bidang pendanaan. Perkembangan usaha asuransi tidak hanya memberi dampak positif pada pemegang polis, perusahaan asuransi dan mereka yang terlibat didalamnya, tetapi juga memberikan kenikmatan pada seluruh anggota masyarakat. Hal ini dapat dilihat pada dana yang dikumpulkan oleh perusahaan asuransi melalui penarikan premi bagi pemegang polis yang oleh perusahaan asuransi akan di investasikan lebih lanjut di bidang bidang bisnis yang produktif. Investasi tersebut akan sangat berperan dalam meningkatkan laju pertumbuhan ekonomi yang hasilnya dapat dinikmati oleh seluruh lapisan masyarakat. Seiring dengan perkembangan bisnis asuransi yang 
semakin cepat maka perusahaan pun mulai meningkatkan layanannya dengan menciptakan layanan yang cepat, efisien dan efektif.

Undang-Undang No. 2 Tahun 1992 tentang Usaha Perasuransian Salah satu upaya untuk menciptakan efisiensi tersebut, perusahaan asuransi menyiapkan draft-draft perjanjian dalam polis asuransinya, dalam bentuk tercetak dan menjadikan kontrak atau perjanjian menjadi baku. Dalam situasi kontrak yang diciptakan dalam keadaan tercetak dan diupayakan dalam bentuk baku oleh perusahaan asuransi, sering terjadi pihak konsumen menjadi pihak yang lemah. Dewasa ini, banyak perusahaanperusahaan asuransi yang menawarkan berbagai jenis polis asuransi yang dapat digunakan atau dimiliki oleh setiap masyarakat, salah satunya seperti yang terdapat pada Sunlife Financial Indonesia. Salah satu produk polis asuransi yang ditawarkan adalah Bancassurance. Bancassurance merupakan suatu produk patungan atau kerjasama antara Bank Penerbit kartu kredit atau rekening tabungan dengan suatu Perusahaan Asuransi. Dalam hal ini, Bank bertugas untuk menjual dengan direct atau tele marketing dan proses pembayaran untuk itu dapat dilakukan dengan autodebet credit card atau rekening tabungan. Sedangkan perusahaan Asuransi, bertugas dalam segala hal yang berhubungan dengan Polis Asuransi, dimulai dari penerbitan polis, claim asuransi, perubahan polis, pemulihan polis, dan lain-lain.

Berkembang pesatnya usahausaha pertanggungan atau perasuransian di Indonesia, baik itu pertanggungan kerugian atau pertanggungan jiwa yang diselenggarakan pemerintah atau swasta menuntun masyarakat untuk mengerti akan tujuan dan manfaat dari salah satu bentuk polis asuransi pada Sunlife Financial Indonesia yaitu Bancassurance. Produk Bancassurance memiliki beberapa varian, mulai dari asuransi pendidikan, asuransi kesehatan, asuransi jiwa, asuransi kecelakaan, sampai dengan investasi.
Namun, kenyataannya jika dibandingkan dengan industri perbankan, industri perasuransian masih kurang banyak mendapat perhatian konsumen khususnya masyarakat dikalangan ds Candikuning. Sebagian besar konsumen atau masyarakat Desa Candikuning cenderung memisahkan sebagian penghasilannya untuk disimpan di bank daripada digunakan untuk asuransi. Konsumen masih sering merasakan bahwa asuransi tak melindungi aktivitasnya, bahkan cenderung merugikannya meskipun kesan itu tak semuanya benar.

Seperti gambaran yang telah dipaparkan di atas, maka sering timbul permasalahan yang pada masyarakat yang ikut sebagai nasabah asuransi. Dalam penjelasan atas undang-undang nomor 8 tahun 1999 tentang perlindungan konsumen, disebutkan antara lain bahwa faktor utama yang menjadi kelemahan konsumen adalah tingkat kesadaran konsumen akan haknya masih rendah. Konsumen cenderung belum memiliki pengetahuan tentang haknya. Hal ini terutama disebabkan oleh pengetahuan konsumen atau masyarakat terhadap asuransi tersebut. Oleh karena itu, Undang-undang Perlindungan Konsumen dimaksudkan menjadi landasan hukum yang kuat bagi pemerintah dan lembaga perlindungan konsumen swadaya masyarakat untuk melakukan upaya pemberdayaan konsumen melalui pembinaan dan pendidikan konsumen.

Perlindungan hukum bagi konsumen adalah suatu masalah yang besar, dengan persaingan global yang terus berkembang. Perlindungan hukum sangat dibutuhkan dalam persaingan dan banyaknya produk serta layanan yang menempatkan konsumen dalam posisi tawar yang lemah. Perlindungan hukum bagi konsumen dalam bentuk perlindungan hukum yang diberikan oleh Negara. Di samping itu, masyarakat Desa Candikuning merasakan masih sedikit informasi yang didapat tentang Perlindungan Hukum bagi pemegang Polis yang terdapat pada Sunlife Financial Indonesia ini. Maka dari itu, penulis 
tertarik mengadakan penelitian mengenai "Faktor-faktor yang mempengaruhi Masyarakat Desa. Candikuning menjadi Nasabah PT. Sun Life Financial Indonesia".

Mengacu pada uraian di atas maka masalah yang dapat dikaji dalam petian ini adalah (1) faktor-faktor yang mempengaruhi Masayarakat Desa Candikuning dalam memutuskan menjadi Nasabah PT. Sun Life Financial Indonesia, (2) faktor-faktor manakah yang paling dominan mempengaruhi keputusan menjadi Nasabah PT. Sun Life Financial Indonesia.

Meninjau dari permasalahan yang ada maka tujuan penelitian ini adalah (a) faktor-faktor apa saja yang mempengaruhi masyarakat Desa Candikuning dalam memutuskan menjadi nasabah PT. Sun Life Financial Indonesia, (b) faktor-faktor yang paling dominan mempengaruhi dalam memutuskan menjadi nasabah di PT. Sun Life Financial Indonesia.

Manfaat dari penelitian ini yaitu, (1) manfaat teoritis hasil penelitian ini diharapkan dapat memberikan wawasan ilmu pengetahuan dalam pengembangan terhadap ilmu ekonomi dalam kaitannya dengan keputusan pembelian asuransi. (2) manfaat praktis dari penelitian ini adalah a) Peneliti, hasil penelitian ini diharapkan dapat menambah wawasan pengetahuan dalam mengaplikasikan teori yang diperoleh selama mengikuti perkuliahan. b) Perusahan Asuransi, sebagai sarana informasi yang dapat digunakan perusahaan untuk mengetahui factor-faktor yang mempengaruhi konsumen untuk menjadi nasabah asuransi dalam perusahaan, c) Lembaga Universitas Pendidikan Ganesha (UNDIKSHA), hasil penelitian ini diharapkan dapat menambah kepustakaan serta referensi bagi mahasiswa sebagai acuan dan dasar penelitian sejenis di masa yang akan datang dan dapat digunakan sebagai bahan perbandingan bagi penelitian selanjutnya, d) Bagi agen asuransi, nasabah asuransi, dan bagi masyarakat atau calon nasabah, hasil penelitian ini diharapkan dapat memberikan gambaran mengenai manfaat asuransi sebagai sebuah alternatif untuk membuat proteksi (perlindungan) dan investasi.

\section{METODE}

Rancangan penelitian merupakan suatu rencana kegiatan yang dibuat oleh peneliti untuk memecahkan masalah, sehingga dapat diperoleh data sesuai dengan tujuan penelitian. Rancangan penelitian pada masyarakat Desa Candikuning yang mengunakan jasa PT. Sun Life Financial Indonesia, merupakan suatu penelitian exploratory research, yaitu penelitian yang bertujuan mencari hubungan-hubungan baru untuk masalah riset. Penelitian yang diorientasikan untuk menentukan faktor-faktor yang memengaruhi nasabah Desa Candikuning mengunakan jasa PT. Sun Life Financial Indonesia. Alat analisis yang digunakan adalah Analisis Faktor.

$$
\text { Populasi merupakan jumlah }
$$

keseluruhan yang mencakup semua anggota yang diteliti (Istijanto, 2009:113). Populasi dalam penelitian ini adalah Masyarakat Desa Candikuning, Kabupaten Tabanan, Bali yang mengunakan jasa PT. Sun Life Financial Indonesia yaitu sebanyak 281 orang (sumber: data PT Sun Life Financial Indonesia Cabang Singaraja tahun 2015). Mengingat besarnya jumlah populasi dalam penelitian ini, maka dalam penelitian ini akan menggunakan sampel. Penentuan jumlah sampel yang digunakan sebagai objek dalam penelitian ini menggunakan rumus Slovin (dalam Husein U mar2005) sebagai berikut:

$$
n=\frac{N}{1+N(e)^{2}}
$$

Keterangan :

$\mathrm{N}=$ ukuran populasi

$n=$ ukuran sampel

$e=$ persentase kelonggaran ketidaktelitian ampling yang masih ditolerir atau diijinkan (10\%)

Populasi jumlah Masyarakat di Desa Candikuning dengan kelonggaran sebesar $10 \%$ dengan menggunakan rumus di atas maka besarnya sampel sebagai berikut: 


$$
\begin{aligned}
& n=-2 \\
& n=1+281(10)^{2} \\
& n=\begin{array}{c}
281 \\
1+281(0.1)
\end{array} \\
& =99.65
\end{aligned}
$$

Jadi besarnya sampel pada penelitian ini adalah sebesar 99.6 dibulatkan menjadi 100 sampel (Masyarakat Desa Candikuning yang menjadi responden). Adapun Desa yang terlibat dalam penelitian ini adalah Desa masyarakat Candikuning, Desa masyarakat Pemuteran, Desa masyarakat Batusesa, Desa masyarakat Bukitcatu dan masyarakat Desa Kembang Merta.
Vol: 9 No: 1 Tahun: 2017

Dalam penelitian ini, proses penarikan sampel dilakukan dengan teknik proportional random sampling untuk mewakili masing - masing Desa dengan menggunakan rumus Slovin (dalam Husein Umar, 2005) sebagai berikut:

$n_{i}=\frac{N_{i}}{N} \times n$

Keterangan:

$n_{i}=$ besarnya sampel di desa ke-i

$N_{i}$ =besarnya populasi pada desa ke-i

$N$ =besarnya keseluruhan populasi

$n$ = besarnya sampel dari populasi

Berikut sampel tiap desa dapat dilihat pada table 1 sebagai berikut.

Tabel 1 Jumlah sampel yang dilibatkan dalam penelitian ini setelah menggunakan Proportional Random Sampling

\begin{tabular}{llcc}
\multirow{2}{*}{ No. } & \multicolumn{1}{c}{ Desa } & \multicolumn{2}{c}{ Jumlah } \\
\cline { 3 - 4 } \cline { 3 - 4 } & & Populasi & Sampel \\
\hline 1 & Candikuning & 40 & $\mathbf{1 4}$ \\
2 & Pemuteran & 157 & 56 \\
3 & Batusesa & 62 & 22 \\
4 & Bukitcatu & 13 & 5 \\
5 & Kembang Merta & 9 & 3 \\
Jumlah & 281 & 100
\end{tabular}

Sumber: data PT Sun Life Financial Indonesia Cabang Singaraja tahun 2015, yang telah diolah oleh peneliti.

Berikut pengambilan sampel untuk masing umur pada setiap banjar yang ada di Desa Candikuning Tabanan Bali dengan menggunakan Stratified Random Sampling, dapat dilihat pada table 2.

Table 2 Stratified Random Sampling.

\begin{tabular}{lccccc}
\hline Umur & $\begin{array}{l}\text { Banjar } \\
\text { Candikuning }\end{array}$ & $\begin{array}{l}\text { Banjar } \\
\text { Pemuteran }\end{array}$ & $\begin{array}{l}\text { Banjar } \\
\text { Batusesa }\end{array}$ & $\begin{array}{l}\text { Banjar } \\
\text { Bukitcatu }\end{array}$ & $\begin{array}{l}\text { Banjar } \\
\text { Kembang } \\
\text { Merta }\end{array}$ \\
\hline $27-32$ & 6 & 19 & 6 & 3 & 2 \\
$33-37$ & 4 & 22 & 9 & 1 & 1 \\
$38-43$ & 4 & 15 & 7 & 1 & - \\
Jumlah & 14 & 56 & 22 & 5 & 3 \\
\hline \multicolumn{2}{c}{$\begin{array}{c}\text { Untuk } \\
\text { responden }\end{array}$} & $\begin{array}{c}\text { mengetahui jawaban dari } \\
\text { (sebagai sampel), yaitu }\end{array}$ & $\begin{array}{l}\text { masyarakat yang dijadikan sampel dalam } \\
\text { penelitian. }\end{array}$ \\
Besarnya sampel pada
\end{tabular}

dengan cara menyebar kuisioner ke

masing-masing desa sesuai jumlah kuota 
p-ISSN : 2599-1418

penelitian ${ }^{259.9-1426}$ in adalah sebesar 99.6 dibulatkan menjadi 100 sampel (Masyarakat Desa Candikuning yang menjadi responden). Adapun Desa yang terlibat dalam penelitian ini adalah Desa masyarakat Candikuning, Desa
Jurnal Pendidikan Ekonomi Undiksha Volume 9 No.1 Tahun: 2017 
masyarakat Pemuteran, Desa masyarakat Batusesa, Desa masyarakat Bukitcatu dan masyarakat Desa Kembang Merta.

Berdasarkan jenisnya, data yang digunakan dalam penelitian ini adalah data kualitatif. Data kualitatif dalam penelitian ini berupa skor jawaban yang diperoleh dari responden (Masyarakat Desa Candikuning yang menjadi Nasabah PT. Sun Life Financial Indonesia) mengenai faktor-faktor yang mempengaruhi Masyarakat Desa Candikuning dalam menggunakan Jasa PT. Sun Life Financial Indonesia dan faktor-faktor yang paling dominan mempengaruhi Masyarakat Desa Candikuning dalam menggunakan Jasa PT. Sun Life Financial Indonesia.

Sesuai dengan rumusan masalah, tujuan penelitian dan jenis data yang dikumpulkan maka analisis data yang digunakan dalam penelitian ini adalah analisis faktor. Suliyanto (2005:114) menyatakan, Analisis faktor adalah suatu teknik untuk menganalisis tentang saling
Jurnal Pendidikan Ekonomi Undiksha Volume 9 No.1 Tahun: 2017

ketergantungan (interdependence) dari beberapa variable secara simultan dengan tujuan untuk menyederhanakan dari bentuk hubungan antara beberapa variable yang diteliti menjadi sejumlah factor yang lebih sedikit dari variable yang diteliti.

\section{HASIL DAN PEMBAHASAN Hasil}

Data yang berhasil dikumpulkan dari kuesioner yang disebarkan dan setelah diolah dengan SPSS 16.0 for Windows menunjukkan faktor-faktor yang mempengaruhi masyarakat desa candikuning menjadi nasabah PT Sun Life Financial Indonesia dapat dijelaskan oleh persentase dari masing-masing faktor. Nilai total Variance Explained digunakan untuk mengetahui persentase dari empat faktor yang dianalisis. Hasil analisis faktor melalui SPSS menunjukkan persentase dari masing-masing faktor dapat dilihat pada Tabel 3 sebagai berikut.

Tabel 3. Total Variance Explained

\begin{tabular}{cllllll} 
Component & \multicolumn{3}{l}{ Initial Eigenvalues } & \multicolumn{3}{c}{ Extraction Sums of Squared Loadings } \\
\cline { 2 - 6 } & Total & $\begin{array}{c}\text { \% of } \\
\text { Varianc }\end{array}$ & $\begin{array}{l}\text { Cumulati } \\
\text { ve \% }\end{array}$ & Total & $\begin{array}{l}\text { \% of } \\
\text { Variance }\end{array}$ & $\begin{array}{l}\text { Cumulative } \\
\%\end{array}$ \\
\hline 1 & 3.835 & 63.915 & 63.915 & 3.835 & 63.915 & 63.915 \\
2 & .885 & 14.756 & 78.671 & & & \\
3 & .815 & 13.588 & 92.259 & & & \\
4 & .278 & 4.626 & 96.886 & & &
\end{tabular}

Berdasarkan tabel diatas dapat dilihat bahwa (1) faktor Budaya memiliki eigenvalue sebesar 3,835 dengan nilai varian sebesar $63,915 \%$, (2) faktor Sosial memiliki eigenvalue sebesar 0,885 dengan nilai varian sebesar $14,756 \%$, (3) faktor Pribadi memiliki eigenvalue sebesar 0,815 dengan nilai varian sebesar 13,588\%, (4) faktor Psikologi memiliki eigenvalue sebesar 0,278 dengan nilai varian sebesar 4,626\% . Jadi, keempat faktor-faktor tersebut mempengaruhi Masyarakat Desa Candikuning menjadi Nasabah PT. Sun Life Financial Indonesia. Untuk menjelaskan faktor yang paling mempengaruhi masyarakat Desa Candikuning menjadi Nasabah PT. Sun Life Financial Indonesia, dapat dilakukan dengan ekstraksi faktor. Ekstraksi faktor dapat dijelaskan oleh total persentase dari masing-masing faktor utama. Faktor-faktor utama tersebut adalah faktor Budaya memiliki nilai parameter eigenvalue > 1 . Untuk mengetahui distribusi dimensi-dimensi yang belum dirotasi kedalam faktor yang telah terbentuk, maka dapat dilihat pada output SPSS 16.0 (Rotated Component Matrix) pada table 4 sebagai berikut. 
Table 4 Faktor yang menjelaskan Masyarakat Desa Candikuning menjadi Nasabah PT. Sun Life Financial Indonesia

\begin{tabular}{|c|c|}
\hline Eigenvalue & d Explained (\%) \\
\hline $\begin{array}{l}\text { Budaya } \\
\text { Sosial }\end{array}$ & $\begin{array}{l}63.915 \\
14.756\end{array}$ \\
\hline $\begin{array}{l}\text { Pribadi } \\
\text { Psikologi }\end{array}$ & $\begin{array}{c}13.588 \\
4.626 \\
\end{array}$ \\
\hline $\begin{array}{l}\text { Berdasarkan dari Tabel diatas } \\
\text { dapat dijelaskan bahwa faktor yang } \\
\text { memiliki eigenvalue }>1 \text { adalah fakor } \\
\text { Budaya, total nilai varianced explained } \\
\text { dari faktor Budaya mampu menjelaskan } \\
\text { sebesar } 63.915 \% \text {. Dengan demikian, } \\
63.915 \% \text { dari seluruh variabel yang ada, } \\
\text { dapat dijelaskan oleh satu faktor yang } \\
\text { terbentuk. Budaya memiliki varianced } \\
\text { explained } 63.915 \% \text {, artinya bahwa faktor } \\
\text { Budaya mampu menjelaskan partisipasi }\end{array}$ & $\begin{array}{l}\text { Masyarakat Desa Candikuning menjadi } \\
\text { Nasabah PT. Sun Life Financial } \\
\text { Indonesia sebesar } 63.915 \% \text {. } \\
\text { Menentukan nama faktor yang } \\
\text { telah terbentuk untuk masing-masing } \\
\text { faktor bersifat subjektif, kadangkala } \\
\text { variabel yang memiliki nilai faktor loading } \\
\text { tertinggi digunakan untuk memberi nama } \\
\text { faktor. Untuk melihat nilai faktor loading } \\
\text { dapat dilihat pada Tabel } 5 \text { sebagai } \\
\text { berikut. }\end{array}$ \\
\hline
\end{tabular}

Table 5 Rotated Component Matrix

Component 1

\begin{tabular}{cl}
\hline Budaya & .914 \\
Sosial & .940 \\
Pribadi & .869 \\
Psikologi & .438
\end{tabular}

Bedasarkan Tabel diatas, faktor yang terbentuk dari faktor budaya, faktor sosial, faktor pribadi, dan faktor Psikologi. Masing-masing kelompok faktor tersebut memiliki loading tertinggi disetiap komponen, yaitu (1) faktor budaya 0,914 , (2) faktor sosial sebesar 0,940, (3) faktor pribadi sebesar 0,869, dan (4) faktor psikologi sebesar 0,438. Faktor yang paling dominan mempengaruhi masyarakat Desa Candikuning menjadi Nasabah PT. Sun Life Financial Indonesia

Table 6 Hasil Anallisis Faktor
Berdasarkan pengujian hipotesis, untuk menentukan dimensi atau faktor yang mempengaruhi masyarakat Desa Candikuning dalam menjadi Nasabah PT Sun Life Financial Indonesia yang paling dominan digunakan parameter koefisien varimax atau mendekati -1 . Nilai yang mendekati 1 diawali oleh nilai 0,50 sedangkan nilai yang mendekati -1 diawali oleh $-0,50$. Secara lebih rinci hasil ringkasan rotasi dari matriks faktor memuat nilai varimax rotation, dapat dilihat pada Tabel 6 sebagai berikut. 
Dimensi atau faktor Masyarakat Desa

Candikuning menjadi Nasabah PT. Sun Life

Financial Indonesia varimax rotation

(\%)

Budaya

63.915

Berdasarkan tabel diatas maka faktor yang paling dominan mempengaruhi partisipasi Masyarakat Desa Candikuning menjadi Nasabah PT. Sun Life Financial Indonesia adalah faktor Budaya dengan varimax rotation 63.915 .

\section{Pembahasan}

Hasil penelitian menunjukkan bahwa partisipasi Masyarakat Desa Candikuning menjadi Nasabah PT. Sun Life Financial Indonesia dipengaruhi oleh faktor budaya, faktor sosial, faktor pribadi, dan faktor Psikologi. Hal ini sesuai dengan teori yang dinyatakan oleh Phillip Kotler (2003:202), bahwa faktor yang mempengaruhi partisipasi, yaitu faktor Budaya, faktor Sosial, faktor Pribadi, faktor Psikologi. Dengan demikian untuk menjelaskan faktor yang mempengaruhi partisipasi Masyarakat Desa Candikuning menjadi Nasabah PT. Sun Life Financial Indonesia, dapat dilihat dari faktor-faktor yang memiliki eigenvalue $>1$, yaitu faktor budaya. Budaya mempunyai pengaruh paling dominan terhadap partisipasi Masyarakat Desa Candikuning menjadi Nasabah PT. Sun Life Financial Indonesia. Budaya merupakan faktor yang paling dominan mempengaruhi partisipasi Masyarakat Desa Candikuning menjadi Nasabah PT. Sun Life Financial Indonesia dibandingkan dengan faktor-faktor lain yang mempengaruhinya. Faktor ini paling dominan disebabkan karena karakteristik masyarakat khusunya masyarakat Desa Candikuning Tabanan Bali mayoritas bekerja di sektor pertaninan, oleh sebab itu maka masyarakat di Desa candikuning Tabanan Bali lebih memilih melindungi diri atau memproteksi dirinya dengan Asurasi PT Sun Life Financial Indonesia. Selain biaya asuransi murah dan terjangkau, pelayanan yang diberikan oleh petugas asurasi tersebut juga sangat ramah dan bersabahat. Ketika ada program - program baru dari asuransi, petugas langusng memberikan informasi sedetail mungkin kepada nasabah asuransi. Budaya, sub budaya, dan kelas sosial sangat penting bagi perilaku pembelian. Budaya merupakan penentu keinginan dan perilaku paling dasar. Anak-anak yang sedang tumbuh akan mendapatkan seperangkat nilai, persepsi, preferensi, dan perilaku dari keluarga dan lembaga-lembaga penting lainnya.

Dalam penelitian ini, kelas sosial sangatlah penting sebagai faktor penentu seseorang untuk melakukan sebuah pembelian. Misalnya budaya, tingkat budaya individu diartikan sebagai patokan dalam budaya nasional suatu negara. Karena besarnya budaya individu atau rumah tangga merupakan gambaran secara tidak langsung dari tingkat kesejahteraan suatu negara. Berkaitan dengan budaya yang diterima tentu akan mempengaruhi perilaku konsumsi.

Hasil penelitian ini sejalan dengan penelitian yang dikemukakan oleh Sumarwan (2004) budaya adalah segala nilai, pemikiran, simbol yang mempengaruhi perilaku, sikap, kepercayaan dan kebiasaan seseorang dan masyarakat. Faktor budaya berupa kebiasaan-kebiasaan yang dilakukan oleh anggota keluarga atau masyarakat sekitar sangat berpengaruh terhadap keputusan pembelian yang dilakukan oleh konsumen. Setiadi (2011) mengungkapkan, bahwa budaya merupakan faktor penentu keinginan dan perilaku seseorang paling mendasar. Dengan kata lain budaya merupakan faktor paling utama dalam perilaku pengambilan keputusan dalam pembelian. Budaya selalu ditanamkan dari satu generasi ke generasi berikutnya, terutama melalui lembaga seperti keluarga, pendidikan agama, dan sekolah. Sehingga nilai-nilai budaya yang ditanamkan sejak kecil melalui keluarga akan tertanam dalam diri individu sejak 
kecil hingga dewasa.

Hasil penelitian menunjukkan bahwa partisipasi Masyarakat Desa Candikuning menjadi Nasabah PT. Sun Life Financial Indonesia dipengaruhi oleh faktor Budaya, faktor Sosial, faktor Pribadi, faktor Psikologi. Hal ini sesuai dengan teori yang dinyatakan oleh Phillip Kotler (2003:202), bahwa faktor yang mempengaruhi partisipasi, yaitu faktor Budaya, faktor Sosial, faktor Pribadi, faktor Psikologi. Dengan demikian untuk menjelaskan yang mempengaruhi partisipasi Masyarakat Desa Candikuning menjadi Nasabah PT. Sun Life Financial Indonesia, dapat dilihat dari faktor-faktor yang memiliki eigenvalue $>1$, yaitu faktor Budaya. Budaya mempunyai pengaruh besar terhadap partisipasi Masyarakat Desa Candikuning menjadi Nasabah PT. Sun Life Financial Indonesia. Budaya merupakan faktor yang paling dominan mempengaruhi partisipasi Masyarakat Desa Candikuning menjadi Nasabah PT. Sun Life Financial Indonesia dibandingkan dengan faktorfaktor lain yang mempengaruhinya. Faktor ini paling dominan disebabkan karena Budaya, sub budaya, dan kelas sosial sangat penting bagi perilaku pembelian. Budaya merupakan penentu keinginan dan perilaku paling dasar. Anak-anak yang sedang tumbuh akan mendapatkan seperangkat nilai, persepsi, preferensi, dan perilaku dari keluarga dan lembaga-lembaga penting lainnya.

Dalam penelitian ini, kelas sosial sangatlah penting sebagai faktor penentu seseorang untuk melakukan sebuah pembelian. Misalnya budaya, tingkat budaya individu diartikan sebagai patokan dalam budaya nasional suatu negara. Karena besarnya budaya individu atau rumah tangga merupakan gambaran secara tidak langsung dari tingkat kesejahteraan suatu negara. Berkaitan dengan budaya yang diterima tentu akan mempengaruhi perilaku konsumsi

\section{SIMPULAN DAN SARAN Simpulan}

Berdasarkan hasil analisis data dan pembahasan, maka dapat ditarik simpulan sebagai berikut.

1) Faktor- faktor yang mempengaruhi partisipasi Masyarakat Desa Candikuning menjadi Nasabah PT. Sun Life Financial Indonesia yaitu sebanyak empat faktor. Faktor-faktor tersebut, diantaranya (a) faktor Budaya yang memiliki eigenvalue sebesar 3,835 dengan nilai varian sebesar $63,915 \%$, (b) faktor Sosial yang memiliki eigenvalue sebesar 0,885 dengan nilai varian sebesar 14,756\%, (c) faktor Pribadi yang memiliki eigenvalue sebesar 0,815 dengan nilai varian sebesar $13,588 \%$, (d) faktor Psikologi yang memiliki eigenvalue sebesar $\quad 0,278$ dengan nilai varian sebesar $4,626 \%$.

2) Faktor yang paling dominan mempengaruhi partisipasi Masyarakat Desa Candikuning menjadi Nasabah PT. Sun Life Financial Indonesia adalah faktor yang berasal dari dalam diri alumni, yaitu faktor Budaya sebesar $63.915 \%$.

\section{Saran}

Berdasarkan simpulan di atas, maka dapat diajukan beberapa saran sebagai berikut.

1. Disarankan kepada Jurusan Pendidikan Ekonomi Fakultas Ekonomi Universitas Pendidikan Ganesha hendaknya memberikan informasi PT. Sun Life Financial Indonesia. Karena dengan partisipasi masyarakat Desa Candikuning menjadi Nasabah PT. Sun Life Financial Indonesia dapat mengembangkan potensi yang dimiliki oleh setiap orang guna mempersiapkan diri menambah bekal dan pengalaman tentang berasuransi.

2. Bagi peneliti lain yang bermaksud melakukan penelitian dibidang Keputusan Pembelian khususnya meneliti tentang keputusan pembelian jasa (Asuransi), diharapakan untuk melakukan penelitian lebih lanjut dan mendalam terkait metode penelitian yang sama dan objek yang berbeda guna keberlakuan temuan ini secara lebih luas.

DAFTAR PUSTAKA 
Agung Nugroho, Bhuono. 2005. "Strategi Jitu Memilih Metode Statistik Penelitian dengan SPSS", Yogyakarta, CV Andi Offset.

Arifin, Zainul. $2005 . \quad$ "Dasa-dasar Manajemen /bank Syariah", Jakarta, Pustaka Alvabet.

Ascarya. 2008. "Akad \& Produk Bank Syariah", Jakarta, PT RajaGrafindo Persada.

Azwar, Saifudin. 2008. Reliabilitas dan Validitas. Edisi ke 3 Cetakan Kedelapan. Yogyakarta: Pustaka Pelajar.

Buchari Alma. 2007. Manajemen Pamasaran dan Pemasaran Jasa. Cetakan Ketujuh (Edisi Revisi). Bandung : Alfabeta.

Fauzana Ilhami. 2009. "Analisis Pengaruh Pelayanan dan Safe Deposite Box Terhadap Keputusan Nasabah Serta Dampaknya pada Loyalitas Nasabah" Jakarta, FEB UIN.

Ghozali, Imam.2005."Aplikasi Analisis Multivariate denga Program SPSS", Semarang, Badan Penerbit Universitas Diponegoro.

Hamid, Abdul. 2007."Buku Panduan Penulisan Skripsi", Jakarta, FEIS UIN Press.

Istijanto, 2009 "Aplikasi Praktis Riset Pemasaran-Cara Praktis Meneliti Konsumen dan Pesaing", Cetakan Kedua, Jakarta, Penerbit PT Gramedia Pustaka Utama.

Karnaen A. Perwataatmadja, Hendri tanjung, 2007 "Bank Syariah", Jakarta, PT Senayan

Kasmir, SE.,MM. ,2008 "Pemasaran Bank", Jakarta, Kencana.

Kotler, Philip dan Armstrong, Gary M. 2012. Principles of Marketing. Edisi Keempatbelas Jilid 1.

Kolter Philip, Kevin Lane Keller, 2007 "Manajemen Pemasaran", Jakarta, PT Indeks.

Kuncoro, Mudrajad, 2003 "Metode Riset untuk Bisnis dan Ekonomi", Jakarta, Erlangga.

Lukman, Dendawijaya. 2003. "Manajemen Perbankan", Jakarta, Kencana.

Nazir,Moh. 2005. Metode Penelitian. Cetakan Kelima, Jakarta : Ghalia Indonesia.
Jurnal Pendidikan Ekonomi Undiksha

Volume 9 No.1 Tahun: 2017

Saladin, Djaslim. 2005. Perilaku konsumen : Konsep dan Implikasi untuk Strategi dan Penelitian Pemasaran. Jakarta: Prenada Media.

Santoso, Singgih. 2004. Buku Latihan SPSS Statistik Parametrik. Jakarta: PT. Elex Media

Paket 27 oktober 1988 dan ketentuan lanjutannya tanggal 29 Januari 1990

Priyatno, Duwi. 2009. "5 Jam Belajar Olah Data dengan SPSS17", Yogyakarta, CV Andi Offset

http://www.forum.kompas.com (Proposal, Skripsi, dan Tesis). (Diakses pada Maret 2016).

http://www.warungasuransi.wordpress.co m (Proposal, Skripsi, dan Tesis). (Diakses pada Maret 2016 